\title{
Penerapan Kurikulum Berbasis KKNI pada Prodi PGMI Unsiq Jawa Tengah
}

\author{
Hendri Purbo Waseso \\ Universitas Sains Al-Qur'an (UNSIQ) Jawa Tengah \\ E-Mail: hendrismp7yk@gmail.com \\ Muhtar Sofwan Hidayat \\ Universitas Sains Al-Qur'an (UNSIQ) Jawa Tengah \\ E-Mail: muhtarsofwan89@gmail.com
}

\begin{abstract}
KKNI based curriculum is relatively new and not a few of the universities in Indonesia are facing obstacles in its implementation so that the learning outcomes that should be owned by the students to be less than optimal. This study aims to determine the application-based curriculum KKNI for a course in PGMI FITK UNSIQ. This is a qualitative study through interviews, observation and documentation as a means of collecting data. Mechanical sampling using purposive sampling and snowball sampling as informants chairman of the study program, lecturers, and students in PGMI UNSIQ in Central Java. The data analysis using techniques Milles and Huberman. The results of this study indicate that the preparation of the applicationbased curriculum in PGMI KKNI is curriculum documents until the stage of determining the study materials, human resources (faculty) recently conducted a lecturer consortium, owned infrastructure has been well prepared. Implementation KKNI based curriculum in PGMI is planning to do the lecturers not been fully focused on KKNI based curriculum, implementation of learning is already oriented to student learning center. If the views of the role of faculty and students in the learning process that has been done has not been effective, and assessment of learning has met three basic activities, namely the lecturers gave ratings assignment, students demonstrated performance, assessed by criteria and instruments that have been created. Especially for the assessment instrument is not shared by all the lecturers.
\end{abstract}

\begin{abstract}
Abstrak
Kurikulum berbasis KKNI relatif baru dan tidak sedikit dari perguruan tinggi Indonesia yang menghadapi hambatan-hambatan dalam penerapannya sehingga capaian pembelajaran yang seharusnya dimiliki oleh mahasiswa menjadi kurang optimal. Penelitian ini bertujuan untuk mengetahui penerapan kurikulum berbasis KKNI pada program studi PGMI FITK UNSIQ. Penelitian ini bersifat kualitatif dengan menggunakan wawancara, observasi dan dokumentasi sebagai alat pengumpul data. Teknik pengambilan sampel menggunakan teknik purposive sampling dan snowball sampling sebagai informan yaitu ketua prodi, dosen, mahasiswa di Prodi PGMI UNSIQ Jawa Tengah. Analisa data menggunakan teknik Milles dan Huberman. Hasil penelitian ini menunjukkan bahwa persiapan dalam penerapan kurikulum berbasis KKNI prodi PGMI yaitu dokumen kurikulumnya baru sampai tahap penentuan bahan kajian, sumber daya manusianya (dosen) baru dilakukan konsorsium dosen PGMI UNSIQ, sarana prasarana yang dimiliki sudah disiapkan secara baik. Penerapan kurikulum berbasis KKNI prodi PGMI yaitu Perencanaan yang dilakukan dosen belum sepenuhnya mengacu pada kurikulum berbasis KKNI, pelaksanaan pembelajaran sudah berorientasi pada student center learning. Jika dilihat dari peran dosen dan mahasiswa dalam proses pembelajaran yang sudah dilakukan belum
\end{abstract}


berjalan efektif, dan penilaian pembelajaran sudah memenuhi tiga aktivitas dasar penilaian yaitu dosen memberi tugas, mahasiswa menunjukkan kinerjanya, dinilai berdasar kriteria dan instrument yang telah dibuat. Khusus untuk instrument penilaian tidak dimiliki oleh semua dosen.

Kata Kunci: KKNI, Kurikulum, PGMI

\section{A. Pendahuluan}

Tuntutan dari diberlakukannya ASEAN Free Trade Area (AFTA) di Indonesia adalah keharusan tersedianya sumber daya manusia berkualitas unggul. Pemerintah telah menjawab tuntutan tersebut dengan merubah paradigma proses pendidikan di perguran tinggi yang mendasarkan pada kerangka kualifikasi nasional Indonesia atau KKNI. Permendikbud No. 73 tahun 2013 diundangkan oleh pemerintah sebagai dasar hukum diwajibkannya penerapan KKNI dalam kurikulum perguruan tinggi di Indonesia. Dalam hal ini, perguruan tinggi memiliki peran strategis sekaligus tanggungjawab yang tidak ringan dalam proses pembentukan sumber daya manusia Indonesia berkualitas unggul.

Penerapan kurikulum yang mengacu KKNI sesungguhnya memperjelas seperti apa profil lulusan dari setiap program studi dan learning outcomes (capaian pembelajaran) seperti apa yang didapatkan mahasiswa setelah mengikuti perkuliahan sehingga penyusunan kurikulum benar-benar didasarkan pada kebutuhan dan kompetensi yang diinginkan setiap prodi (Nur Hasanah, 2014: 206). Pentingnya penerapan kurikulum program studi berbasis KKNI terletak pada standarisasi kompetensi mahasiswa dari prodi yang sama melalui level-level yang sudah ditetapkan. Dalam hal ini, penyusunan kurikulum antar perguruan tinggi memiliki sedikit kemungkinan dalam perbedaan out put yang dihasilkan dikarenakan sudah ada ketentuan capaian pembelajaran secara nasional. Sehingga mahasiswa lulusan prodi PGMI UNSIQ Jawa Tengah dengan mahasiswa lulusan prodi PGMI UIN Sunan Kalijaga misalnya tidak berbeda dalam hal kualifikasi nasional yang dihasilkan.

Kurikulum berbasis KKNI dimaksudkan agar dapat mengurangi kesenjangan antara kompetensi kebutuhan dunia kerja dengan mutu lulusan suatu lembaga pendidikan. Sinkronisasi hal tersebut berdampak pada penyerapan tenaga kerja secara efektif dan sesuai dengan bidangnya masing-masing serta memiliki kompetensi yang diharapkan. Dari sudut pandang sumber daya manusia, dampak dari penerapan kurikulum berbasis KKNI adalah manusia Indonesia harus memiliki sikap dan tata nilai ke-Indonesia-an, kemampuan, pengetahuan sekaligus mendapat tanggungjawab dan hak atas capaian pembelajaran yang dilakukannya sesuai dengan level dalam KKNI (Tim Belmawa-Dikti, 2014: 14). Sedangkan dari segi penguatan kelembagaan, Muhammad Zein menyatakan bahwa kurikulum berbasis KKNI berguna untuk menguatkan dan meningkatkan kompetensi dosen dan mahasiswa serta untuk meningkatkan level suatu perguruan tinggi dari segala aspek dan lingkungannya (www.edukasi.fajarnews.com, tanggal akses 5 Maret 2016). Artinya, kurikulum berbasis KKNI memiliki urgensitas 
tinggi untuk segera diterapkan oleh semua program studi pada perguruan tinggi di Indonesia.

Dalam praktiknya, tidak semua perguruan tinggi dapat menerapkan kurikulum berbasis KKNI dengan mulus tanpa kendala, baik karena faktor ketidaksiapan secara SDM maupun perangkat yang belum memadai. Sebagai produk baru, kurikulum berbasis KKNI memang membutuhkan waktu yang lama baik dalam persiapan, penyusunan maupun dalam penerapan kurikulumnya. Casmini menyebut sulitnya penyusunan kurikulum jurusan BKI berbasis KKNI yang mengacu pada tuntutan dan kebutuhan masyarakat pengguna BKI sehingga diperlukan evaluasi dan peninjauan kembali (Casmini, 2014: 143). Mengetahui bagaimana penerapan kurikulum berbasis KKNI pada semua program studi termasuk dalam konteks penelitian ini adalah program studi PGMI UNSIQ Jawa Tengah, menemukan signifikansinya dalam rangka pencarian informasi berbasis riset mengenai rekomendasi yang tepat dalam proses penerapan kurikulum berbasis KKNI.

Sesuai dengan amanat dari PP 19 tahun 2005 tentang Standar Nasional Pendidikan, yang menyebutkan persyaratan guru MI berijazah D4 atau S1, Program Studi PGMI UNSIQ Jawa Tengah hadir dalam rangka menjawab kebutuhan calon-calon guru MI yang diharuskan memiliki kompetensi pedagogi, kepribadian, professional dan sosial. Lebih dari itu, kualitas lulusan prodi PGMI UNSIQ Jawa Tengah yang berdaya saing global dapat menjadi indikator peningkatan sumber daya manusia. Karena itu, Program studi Pendidikan Guru MI (PGMI) UNSIQ Jawa Tengah telah mempersiapkan penerapan kurikulum berbasis KKNI mulai tahun 2015/2016. Selain prodi PGMI UNSIQ, Perguruan Tinggi Islam Negeri seperti STAIN Salatiga, STAIN Pekalongan, UIN Walisongo Semarang telah melakukan kegiatan workshop penyusunan kurikulum PGMI berbasis KKNI sepanjang tahun 2015. Bahkan Perguruan Tinggi Islam Swasta seperti FAI UNSIQ dan IPMAFA Pati juga melakukan hal yang sama agar penerapan kurikulum KKNI dapat menghasilkan lulusan yang bermutu.

Di Prodi PGMI UNSIQ sendiri, proses awal dalam merumuskan draft capaian pembelajaran telah dirapatkan secara umum di tingkatan universitas pada tanggal 28 Januari 2015 dengan dihadiri oleh semua kaprodi di lingkungan UNSIQ. Kendala yang dihadapi beberapa prodi dalam merumuskan draft capaian pembelajaran adalah tidak adanya asosiasi prodi serta belum adanya profil lulusan dari universitas (unsiq.ac.id, tanggal akses 1 Maret 2016).

Dari urgensitas penerapan kurikulum berbasis KKNI dan problemnya tersebut, menarik untuk dikaji lebih lanjut dalam suatu rambu-rambu ilmiah tentang bagaimana penerapan kurikulum berbasis KKNI pada program studi PGMI UNSIQ Jawa Tengah. Dalam penelitian ini, siklus penerapan kurikulum perguruan tinggi sebagai kerangka teori, diharapkan pemecahan masalah dalam penelitian ini dapat terselesaikan. Analisa terhadap bagaimana penerapan kurikulum berbasis KKNI pada Prodi PGMI UNSIQ Jawa Tengah menjadi penting dilakukan. Dikarenakan, rekomendasi berbasis riset atas penerapan kurikulum KKNI Prodi PGMI dapat meningkatkan mutu pembelajaran sekaligus dapat menguatkan secara kelembagaan. 


\section{B. Kerangka Teori}

\section{Kerangka Kualifikasi Nasional Indonesia (KKNI)}

Dalam Permendikbud No. 73 Tahun 2013 dijelaskan bahwa kerangka kualifikasi nasional Indonesia (KKNI) bidang perguruan tinggi merupakan kerangka penjenjangan kualifikasi yang dapat menyandingkan, menyetarakan, dan mengintegrasikan capaian pembelajaran dari jalur pendidikan nonformal, pendidikan informal, dan/atau pengalaman kerja ke dalam jenis dan jenjang pendidikan tinggi. Dorongan utama dari diperlukannya KKNI ini adalah berawal dari problem keselarasan mutu dan penjenjangan produk lulusan perguruan tinggi dengan kriteria tenaga kerja yang diharapkan oleh masyarakat pengguna lulusan. Keluhan terhadap kesenjangan antara jumlah, mutu dan kemampuan lulusan terhadap kriteria yang dibutuhkan oleh dunia kerja sering mengemuka (Dikti, 2010: 4). Dalam kerangka inilah, KKNI mulai dirasa penting untuk segera dirumuskan untuk mengantisipasi problematika yang lebih kompleks baik di bidang pendidikan tinggi maupun bidang tenaga kerja Indonesia.

KKNI disusun berdasarkan kebutuhan dan tujuan khusus yang khas bagi Indonesia untuk menyelaraskan sistem pendidikan dan pelatihan dengan sistem karir di dunia kerja. KKNI juga dirancang untuk sesuai dan setara dengan sistem yang dikembangkan negara-negara lain (Dikti, 2010: 4). KKNI terdiri dari 9 jenjang kualifikasi. Di bawah ini merupakan gambaran penjenjangan setiap level dalam KKNI yang dibuat oleh Dikti yakni sebagai berikut:

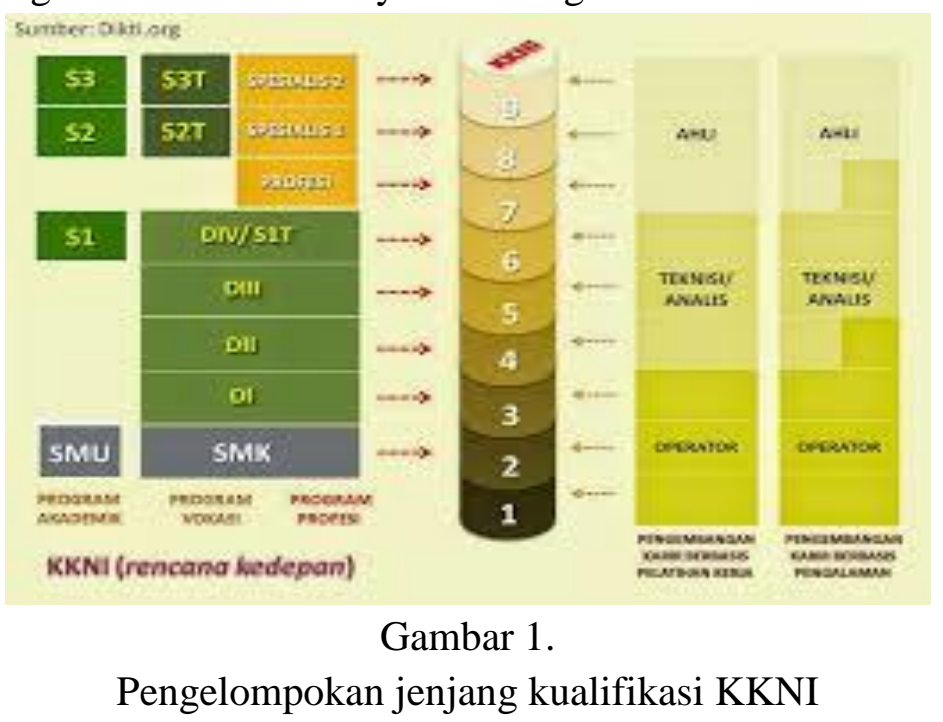

Secara konseptual, setiap jenjang kualifikasi dalam KKNI disusun oleh empat parameter, yaitu: (1) keterampilan kerja, (2) cakupan keilmuan (pengetahuan), (3) metode dan tingkat kemampuan mengaplikasikan keilmuan, dan (4) kemampuan manajerial. Internalisasi dan akumulasi keempat parameter yang harus dicapai melalui proses pendidikan yang terstruktur atau melalui pengalaman kerja disebut dengan learning outcomes atau capaian pembelajaran (Imroatus Solikhah, 2015: 5). Keempat 
parameter dalam setiap jenjang kualifikasi KKNI dapat diilustrasikan dalam gambar berikut:

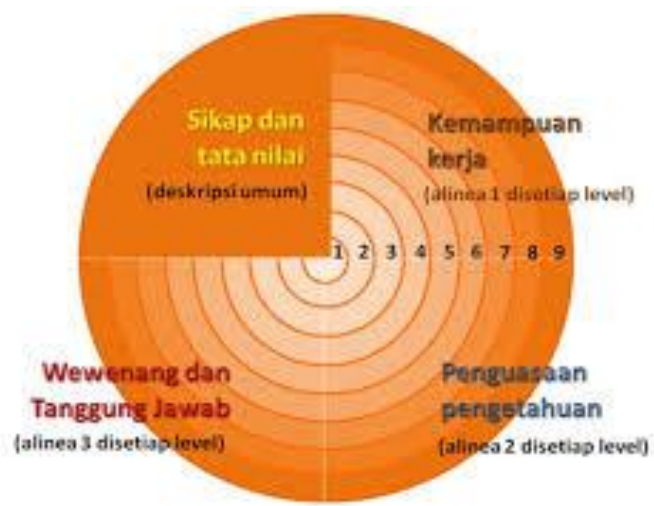

Gambar 2 Parameter setiap jenjang kualifikasi KKNI ( kkni-kemenristekdikti.org)

Penjenjangan dan parameter dalam KKNI selanjutnya dapat dikembangkan di masa yang akan datang. Pengembangan KKNI tersebut berdasarkan pada tiga alasan utama. Pertama, KKNI menganut strategi kesetaraan kualifikasi seseorang yang diperoleh dari dunia pendidikan formal, nonformal, informal dan pengalaman bekerja. Kedua, KKNI mengakui kualifikasi pemegang ijazah yang akan bekerja maupun melanjutkan pendidikan di luar negeri, pertukaran pakar dan mahasiswa lintas negara atau pemegang ijazah dari luar negeri yang bekerja di Indonesia. Ketiga, KKNI mengakui kesetaraan kualifikasi capaian pembelajaran berbagai bidang keilmuan pada tingkat pendidikan tinggi, baik yang berada pada jalur pendidikan akademik, vokasi, profesi, serta melalui pengembangan karir yang terjadi di strata kerja, industri atau asosiasi profesi (Dikti, 2010: 11).

\section{Implementasi atau Penerapan Kurikulum Berbasis KKNI}

Implementasi adalah melaksanakan sesuatu atau aplikasi praktis dari metode dan prosedur atau tujuan yang diinginkan (Achmad Ridwan, 2016). Menurut Sulistyastuti implementasi intinya adalah kegiatan untuk mendistribusikan keluaran kebijakan (to deliver policy output) yang dilakukan oleh para implementor kepada kelompok sasaran (target group) sebagai upaya untuk mewujudkan kebijakan (Dyah Ratih Sulistyastuti, 2012: 21). Asumsi utama dari konsep implementasi adalah penerapan suatu produk kebijakan dalam rangka mencapai suatu tujuan tertentu.

Dalam menganalisis masalah implementasi, Charles O. Jones mengartikan penerapan atau implementasi sebagai suatu aktifitas yang dimaksudkan untuk mengoperasikan sebuah program (Arif Rohman, 2009: 135). Ada tiga pilar dalam mengoperasikan program tersebut, yaitu:

a. Pengorganisasian, pembentukan atau penataan kembali sumberdaya, unit-unit serta metode untuk menjalankan program agar bisa berjalan;

b. Interpretasi, aktifitas menafsirkan agar program menjadi rencana dan pegarahan yang tepat dan dapat diterima serta dilaksanakan; 
c. Aplikasi, berhubungan dengan perlengkapan rutin bagi pelayanan, pembayaran, atau yang lainnya yang disesuaikan dengan tujuan atau perlengkapan program.

Operasionalisasi kurikulum berbasis KKNI pada prodi PGMI UNSIQ selanjutnya dianalisa melalui ketiga pilar implementasi tersebut. Pengorganisasian sumber daya untuk menerapkan kurikulum, interpretasi mereka terhadap kurikulum berbasis KKNI, dan pengaplikasian peran yang dibebankan kepada pihak-pihak seperti dosen maupun mahasiswa dalam rangka penerapan kurikulum berbasis KKNI.

Lebih khusus, implementasi kurikulum perguruan tinggi didefinisikan oleh Loucks dan Lieberan dalam Ridwan (2016) sebagai mencoba praktik baru dan apa yang akan tampak ketika benar-benar digunakan dalam sistem kampus. Selanjutnya diharapkan suatu perubahan menuju perbaikan-perbaikan yang diinginkan. Penerapan kurikulum berbasis KKNI sebagai suatu program juga diharapkan membawa perbaikanperbaikan kualitas out put mahasiswa.

\section{Hasil Penelitian dan Pembahasan}

1. Persiapan Penerapan Kurikulum Berbasis KKNI

a. Proses Penyusunan Kurikulum Berbasis KKNI

Dalam proses penyusunan kurikulum berbasis KKNI, Prodi PGMI UNSIQ telah melakukan berbagai macam tingkatan proses yaitu: Pertama, tingkatan universitas. Workshop penyusunan kurikulum berbasis KKNI yang dilaksanakan oleh universitas pada hari kamis, 18 Desember 2014. Dalam workshop tersebut, UNSIQ menghadirkan pakar KKNI yaitu Sylvi Dewajani dari UGM Yogyakarta. Kedua, tingkat Fakultas. Penyusunan kurikulum berbasis KKNI pada prodi PGMI dilanjutkan dibawah kordinasi fakultas. Fakultas membentuk tim khusus yang terdiri dari tim-tim kecil penyusun kurikulum prodi. Ketiga, tingkat Program Studi. Tim pengembang kurikulum berbasis KKNI untuk prodi PGMI kemudian secara intens merumuskan dokumen kurikulum.

Berdasarkan tahapan proses penyusunan kurikulum berbasis KKNI tersebut, prodi PGMI setidaknya telah melewati berbagai macam tahapan. Secara kronologis, tahun 2014 merupakan tahap perkenalan yang ditunjukkan dengan adanya workshop universitas. Dengan adanya workshop tersebut, setiap prodi di lingkungan UNSIQ termasuk prodi PGMI mengenal istilah-istilah yang terdapat dalam kurikulum berbasis KKNI seperti profil lulusan dan capaian pembelajaran. Pada tahun 2015 awal, prodi PGMI mulai masuk dalam tahap pemahaman dan pendalaman tentang bagaimana penyusunan kurikulum berbasis KKNI. Tahap ini, prodi PGMI bersama prodi lain mulai mencoba menyusun kurikulum berbasis KKNI secara mandiri tanpa pendampingan. Pada bulan September 2015, kurikulum berbasis KKNI prodi PGMI mulai diujicobakan pada semester 1 tahun ajaran 2015/2016. Ujicoba penerapan kurikulum tersebut mendayagunakan dosen tetap prodi PGMI untuk menyusun silabus atau rencana pembelajaran semester (RPS).

Sebagai bagian dari persiapan penerapan kurikulum berbasis KKNI, penyusunan kurikulum prodi PGMI sudah dapat terlaksana dengan berbagai macam kekurangannya. Hasil dari penyusunan tersebut adalah produk dokumen atau draft kurikulum berbasis 
KKNI prodi PGMI UNSIQ. Dokumen kurikulum berbasis KKNI pada Prodi PGMI tersebut, dapat dihasilkan analisa sebagai berikut:

Profil lulusan yang dimiliki oleh prodi PGMI UNSIQ adalah (a) Guru Kelas Madrasah Ibtidaiyyah Profesional; (b) Peneliti Pendidikan dalam bidang ke-MI-an; (c) Pengelola Madrasah Ibtidaiyyah; dan (d) Edupreuner Handal (Dokumentasi Kurikulum Berbasis KKNI Prodi PGMI UNSIQ, 2016). dalam proses perumusan profil lulusan tersebut, prodi PGMI tidak melibatkan stakeholder atau pengguna lulusan. Hal tersebut diketahui berdasarkan wawancara dengan tim pengembang kurikulum, Muhtar Sofwan Hidayat. Dari wawancara tersebut dihasilkan bahwa proses perumusan profil lulusan prodi PGMI disusun oleh tim pengembang kurikulum KKNI untuk prodi PGMI yang ditugaskan oleh Fakultas yaitu Nasokah selaku Kaprodi, Muhtar Sofwan Hidayat dan Arina Hidayati (22 September 2016). Sedangkan dalam buku panduan kurikulum pendidikan tinggi oleh tim Belmawa-Dikti disebutkan bahwa seyogyanya profil lulusan program studi disusun oleh kelompok prodi sejenis. Selain itu, keterlibatan stakeholder juga akan memberikan kontribusi untuk memperoleh konvergensi dan konektivitas antara institusi pendidikan dengan pemangku kepentingan yang nantinya akan menggunakan hasil didiknya (Tim Belmawa-Dikti, 2014: 32). Artinya, profil lulusan yang disusun oleh prodi PGMI belum mencerminkan harapan pengguna lulusan secara nyata.

Capaian pembelajaran sendiri dalam istilah lain dapat disebut sebagai tujuan pembelajaran. Dalam buku panduan penyusunan capaian pembelajaran lulusan program studi, capaian pembelajaran didefinisikan sebagai kemampuan yang diperoleh melalui internalisasi pengetahuan, sikap, keterampilan, kompetensi, dan akumulasi pengalaman kerja (Tim Belmawa-Dikti, 2014: 32). Berdasarkan analisa terhadap dokumen kurikulum berbasis KKNI prodi PGMI UNSIQ tentang matriks profil dan capaian pembelajaran, capaian pembelajaran yang disusun untuk setiap unsur adalah sebagai berikut:

a) Sikap

Capaian pembelajaran unsur sikap ini sudah sesuai dengan deskripsi umum yang ada pada Perpres, terdiri dari enam sikap yang harus dimiliki oleh mahasiswa. Capaian pembelajaran aspek sikap tersebut dicantumkan di awal dokumen kurikulum terpisah dengan capaian pembelajaran unsur lainnya. Hal tersebut dikarenakan capaian sikap ini tidak secara langsung dibuatkan bahan kajian, namun menjadi satu kesatuan dengan capaian pembelajaran lain atau diintegrasikan dalam setiap mata kuliah yang ada. Deskripsi tersebut juga sama persis dengan deskripsi yang ada dalam Perpres No. 08 tahun 2012.

b) Ketrampilan Umum

Capaian pembelajaran unsur ketrampilan umum diambil dari lampiran permendikbud No. 49 Tahun 2014 yang berjumlah sembilan capaian pembelajaran. Dalam pengkategoriannya, capaian pembelajaran ini disesuaikan dengan profil lulusan prodi PGMI. Sebenarnya tidak ada acuan khusus mengenai pengkategorian capaian pembelajaran unsur ketrampilan umum pada profil lulusan program studi. Artinya, 
pencantuman ketrampilan umum sesuai dengan rumusan standar nasional pendidikan tinggi dalam kurikulum berbasis KKNI prodi PGMI sudah dianggap cukup. Bahkan dalam hal pengkategorian yang tidak tepat justru memunculkan problem tersendiri.

c) Pengetahuan dan Ketrampilan Khusus

Dalam hal rumusan capaian pembelajaran aspek pengetahuan dan ketrampilan khusus, dokumen kurikulum KKNI prodi PGMI tentang matriks dan capaian pembelajaran tidak disebutkan secara eksplisit pengkategoriannya. Tetapi istilah yang digunakan adalah capaian pembelajaran khusus (ditetapkan asosiasi prodi) dan capaian pembelajaran penciri perguruan tinggi (ditetapkan oleh perguruan tinggi sendiri). Meskipun begitu, peneliti memposisikan capaian pembelajaran khusus dan capaian pembelajaran penciri perguruan tinggi dalam kurikulum berbasis KKNI prodi PGMI sebagai unsur pengetahuan dan ketrampilan khusus. Hal tersebut dikarenakan kewenangan untuk pengembangan pada unsur ini diserahkan pada setiap prodi atau perguruan tinggi masing-masing.

Dalam capaian pembelajaran khusus terdapat 24 capaian pembelajaran. Dari ke 24 capaian pembelajaran tersebut ditemukan beberapa capaian pembelajaran yang tidak sesuai dengan bidang keilmuan prodi PGMI. Padahal dalam panduan penyusunan capaian pembelajaran disebutkan bahwa keterampilan khusus merupakan kemampuan kerja khusus yang wajib dimiliki oleh setiap lulusan sesuai dengan bidang keilmuan program studi.

Bahan kajian ini bisa langsung dideskripsikan sebagai mata kuliah yang harus ditempuh oleh mahasiswa. Keluasan dan kedalaman bahan kajian ditetapkan dengan merujuk pada capaian pembelajaran. Tingkat keluasan dan kedalaman bahan kajian untuk lulusan program sarjana berdasarkan pasal 9 Permendikbud No 49 Tahun 2014 yaitu paling sedikit menguasai konsep teoritis bidang pengetahuan dan keterampilan tertentu secara umum dan konsep teoritis bagian khusus dalam bidang pengetahuan dan ketrampilan tersebut secara mendalam (Permendikbud No. 49 Tahun 2014).

Berdasarkan dokumen kurikulum berbasis KKNI prodi PGMI, bahan kajian disusun dengan mengacu pada capaian pembelajaran yang ada kemudian mengklasifikasikannya ke dalam tema-tema keilmuan mata kuliah-mata kuliah. Tematema keilmuan tersebut yaitu tema nasional, agama dan akhlak mulia, ke-al-Qur'an-an, pendidikan dan keguruan, kesehatan, bahasa dan seni budaya, ilmu dan teknologi, dan praktik.

Berdasarkan bahan kajian yang sudah disusun tersebut, terdapat satu capaian pembelajaran yang belum memiliki bahan kajian yang ditetapkan. Capaian pembelajaran tersebut adalah mampu mengambil keputusan yang tepat berdasarkan analisis informasi dan data, dan mampu memberikan petunjuk dalam memilih berbagai alternatif solusi secara mandiri dan kelompok (Dokumentasi Kurikulum Berbasis KKNI Prodi PGMI UNSIQ). Selain itu, jumlah capaian pembelajaran yang merupakan gabungan dari aspek pengetahuan dan ketrampilan yang disusun oleh prodi/perguruan tinggi dan SN-Dikti seharusnya 38 capaian pembelajaran. Namun, dalam kurikulum berbasis KKNI prodi PGMI tentang penetapan bahan kajian dan mata kuliah di sana 
hanya tercantum 27 capaian pembelajaran saja. Artinya memang bahan kajian yang disusun belum sempurna sebagaimana yang disampaikan oleh tim pengembang kurikulum.

Dalam dokumen kurikulum berbasis KKNI selain rumusan profil lulusan, capaian pembelajaran, dan bahan kajian, minimal terdapat rumusan metode pembelajaran dan penilaian yang digunakan (Tim Belmawa-Dikti, 2014: 30). Sedangkan dalam dokumen kurikulum berbasis KKNI PGMI UNSIQ tidak terdapat komponen metoda pembelajaran dan penilaian. Dalam hal ini, dokumen kurikulum berbasis KKNI prodi PGMI UNSIQ memang belum sempurna sesuai dengan panduan penyusunan yang telah diberlakukan.

b. Sumber Daya Manusia

Sumber daya manusia dalam proses penerapan kurikulum berbasis KKNI pada prodi PGMI menjadi penting untuk diperhatikan agar tujuan-tujuan utama prodi tersebut dapat tercapai. Kesiapan sumber daya manusia berpengaruh terhadap pola penerapan di lapangan sehingga diperlukan manajemen yang baik dari pengelola. Untuk kesiapan sumber daya manusia dalam penerapan kurikulum berbasis KKNI pada prodi PGMI UNSIQ dapat dijelaskan sebagai berikut:

Dosen, dalam konteks penerapan kurikulum berbasis KKNI, dosen memiliki posisi sebagai penafsir kurikulum yang diterjemahkan ke dalam proses pembelajaran yang dilakukan. Seberapa jauh pemahaman dosen mengenai KKNI berpengaruh terhadap pembelajaran di kelas. Berdasarkan data yang diperoleh, ditemukan bahwa pemahaman dosen PGMI mengenai kurikulum KKNI tidak secara menyeluruh memiliki pemahaman yang utuh. Hal tersebut dikarenakan kurangnya sosialisasi dan up to date dosen terhadap kurikulum.

Karyawan, di sini bertugas untuk mengurusi berbagai macam keadministrasian dan kelengkapan sekaligus sarana yang diperlukan. Karyawan atau staf di prodi PGMI menjadi satu kesatuan dibawah kendali fakultas. Staf yang khusus melayani baik kebutuhan dosen maupun mahasiswa untuk prodi PGMI adalah Arina Hidayati.

c. Sarana dan prasarana

Dari segi sarana prasarana, prodi PGMI telah memiliki ruang kuliah yang sudah dilengkapi proyektor dan whiteboard. Selain itu, terdapat juga perpustakaan fakultas, perpustakaan universitas, laboratorium MIPA, laboratorium micro teaching dan tempat ibadah. Sarana dan prasarana tersebut digunakan secara bergantian dengan prodi lain dibawah kontrol fakultas. Dari sarana dan prasarana yang dimiliki tersebut dapat dikatakan sudah memenuhi standar yang telah ditetapkan dari segi kelengkapan dan kuantitasnya. Sedangkan sarana prasarana yang masih belum optimal adalah tersedianya jaringan internet untuk mahasiswa yang memiliki konektivitas cepat. Hal tersebut berpengaruh terhadap akses mahasiswa mengenai berbagai sumber yang didapatkan dari internet.

\section{Penerapan Kurikulum Berbasis KKNI}


Dalam menganalisis masalah penerapan, Charles O. Jones mengartikan penerapan atau implementasi sebagai suatu aktifitas yang dimaksudkan untuk mengoperasikan sebuah program (Arif Rohman, 2009: 135). Kurikulum berbasis KKNI pada prodi PGMI UNSIQ telah diterapkan dengan penjelasan sebagai berikut: pertama, pengorganisasian. Dalam tahap pengorganisasian ini, kurikulum berbasis KKNI prodi PGMI telah disusun dengan melibatkan tim universitas yaitu mengadakan kegiatan workshop kurikulum, tim fakultas yaitu memfasilitasi penyusunan kurikulum bersama prodi lain dengan membentuk tim pengembang kurikulum prodi, dan tim pengembang kurikulum dari prodi dengan tugas penyusunan kurikulum dan sosialisasi kepada dosen dengan mengadakan kegiatan konsorsium dosen PGMI. Meskipun setiap tahap pengorganisasian ini tidak berjalan maksimal sampai pada penyusunan strategi penerapan kurikulum berbasis KKNI, namun penerapan kurikulum berbasis KKNI dapat berjalan sesuai jadwal yang telah direncanakan.

Kedua, interpretasi. Tahap kedua ini masih banyak mengalami kendala seperti masih bingungnya tim pengembang kurikulum sehingga konsorsium dosen yang bertujuan untuk mensosialiasasikan kurikulum berbasis KKNI prodi KKNI pun tidak sesuai harapan. Implikasinya adalah pemahaman dosen tentang kurikulum KKNI ini tidak merata pada semua dosen PGMI UNSIQ. Meskipun demikian, pemahaman singkat dosen PGMI tentang berlakunya kurikulum berbasis KKNI direspon positif.

Ketiga, aplikasi. Menjadi lanjutan dari tahap sebelumnya, aplikasi ini merupakan tahap yang belum dapat ditunjukkan mengenai diterapkannya kurikulum berbasis KKNI dengan tujuan pemberlakuannya. Hal tersebut dikarenakan penerapan kurikulum berbasis KKNI prodi PGMI masih bersifat ujicoba.

Selain Charles O. Jones, persoalan penerapan atau implementasi dapat juga dianalisa dengan pendekatan-pendekatan prosedural dan manajerial (procedural and managerial approaches) yang oleh Solichin Abdul Wahab disebutkan bahwa tahap implementasi mencakup urut-urutan langkah sebagai berikut:

1. Merancang bangun (mendesain) program beserta perincian tugas dan perumusan tujuan yang jelas, penentuan ukuran prestasi kerja, biaya dan waktu;

2. Melaksanakan program, dengan mendayagunakan struktur-struktur dan personalia, dana dan sumber-sumber, prosedur-prosedur, dan metode-metode yang tepat;

3. Membangun sistem penjadwalan, monitoring, dan sarana-sarana pengawasan yang tepat guna menjamin bahwa tindakan-tindakan yang tepat dan benar dapat segera dilaksanakan (Sholichin Abdul Wahab, 2008: 112).

Dari rangkaian tahap diatas, secara garis besar implementasi kebijakan meliputi kegiatan perencanaan, penjadwalan, dan pengawasan. Penerapan kurikulum berbasis KKNI pada prodi PGMI jika dianalisa dari ketiga tahapan implementasi tersebut dapat dijelaskan sebagai berikut: pertama, perencanaan. Perencanaan terkait penerapan kurikulum berbasis KKNI pada prodi PGMI telah dilaksanakan dengan berbagai macam tahapan seperti penyusunan kurikulum, sosialisasi kurikulum dan pelaksanaan kurikulum. Perencanaan tersebut disesuaikan dengan rencana kegiatan oleh universitas dan fakultas. Kedua, penjadwalan. Penjadwalan ini berupa target-target atau deadline 
tentang setiap tahap yang telah direncanakan. Meskipun demikian, tidak ditemukan dokumentasi terkait jadwal yang dimaksud. Menurut hasil wawancara bahwa dokumen kurikulum berbasis KKNI waktu itu harus selesai pada bulan Juli 2015 (Hasil Wawancara dengan Muhtar Sofwan Hidayat pada tanggal 22 September 2016). Dan ketiga, pengawasan. Sistem pengawasan dalam penerapan kurikulum berbasis KKNI ini tidak berjalan maksimal. Hal tersebut dikarenakan kurangnya pendampingan oleh pemerintah. Tidak ada tim khusus yang diterjunkan baik oleh koordinator perguruan tinggi maupun dari kementerian secara langsung. Selain itu, penerapan kurikulum berbasis KKNI ini berbarengan dengan berlakunya peraturan terkait pemenuhan enam dosen untuk setiap prodi. Walhasil, terutama perguruan tinggi swasta fokus dengan pemenuhan tersebut.

Selanjutnya, aktivitas pembelajaran yang dilakukan oleh dosen dan mahasiswa merupakan aplikasi secara langsung mengenai kurikulum yang telah dirumuskan pada tahap sebelumnya. Aktivitas pembelajaran ini menggambarkan keterlaksanaan kurikulum berbasis KKNI pada prodi PGMI UNSIQ. Dalam hal ini, interpreter utama ke dalam aktivitas pembelajaran adalah dosen. Posisi dosen di sini adalah melaksanakan pembelajaran sesuai dengan capaian pembelajaran yang diusahakan tercapai oleh mahasiswa melalui mata kuliah-mata kuliah atau bahan kajian. Tugas dosen dalam penerapan kurikulum berbasis KKNI prodi PGMI UNSIQ adalah merencanakan perkuliahan, melaksanakan dan mengevaluasi mahasiswa. perencanaan ini berkaitan dengan dokumen rencana pembelajaran semester (RPS). Pelaksanaan berkaitan dengan proses pembelajaran yang dilakukan dengan mengacu pada RPS yang telah dibuat. Evaluasi berkaitan dengan penilaian terhadap proses belajar mahasiswa dan hasil akhir belajar mahasiswa.

Berdasarkan data yang dikumpulkan oleh peneliti, berikut deskripsi mengenai penerapan kurikulum berbasis KKNI pada prodi PGMI UNSIQ.

Perencanaan. Dalam penelitian ini, rencana yang dianalisa oleh peneliti adalah rencana mata kuliah dari dosen yang mengajar pada semester 1 dan 3 . Hal tersebut dikarenakan kurikulum KKNI prodi PGMI baru diterapkan pada semester 3 dan 1. RPS yang diteliti adalah mata kuliah Metodologi Studi Islam yang diampu oleh Muhtar Sofwan Hidayat, M.Pd.I, Ilmu Pendidikan Islam diampu oleh Hendri Purbo Waseso, M.Pd.I, Psikologi Pendidikan diampu oleh Salis Wahyu Hidayati, M.Pd dan mata kuliah IPS MI/SD diampu oleh Pamungkas Stiya Mulyani, M.Pd. Istilah yang digunakan dalam dokumen perencanaan adalah satuan acara perkuliahan (SAP). Dari empat dokumen SAP tersebut, dapat dikatakan bahwa belum ada perencanaan yang sesuai dengan atau mengacu pada capaian pembelajaran dalam kurikulum berbasis KKNI prodi PGMI. Hal tersebut dikarenakan masih belum sempurnanya dokumen kurikulum berbasis KKNI prodi PGMI sehingga dosen tetap menggunakan perencanaan yang biasanya digunakan. Selain itu, dokumen SAP belum ada keterkaitan antara capaian pembelajaran dalam kurikulum berbasis KKNI prodi PGMI dengan rencana perkuliahan yang disusun oleh dosen. 
Pelaksanaan.Paradigma pembelajaran dalam kurikulum berbasis KKNI adalah pembelajaran yang berpusat pada mahasiswa (student center learning). Dalam student center learning ini terdapat tiga prinsip utama yang harus ada dalam pembelajaran yang dilakukan yaitu memandang pengetahuan sebagai satu hal yang belum lengkap, memandang proses belajar sebagai proses untuk merekonstruksi dan mencari pengetahuan yang akan dipelajari dan memandang proses pembelajaran bukan sebagai proses pengajaran yang dapat dilakukan secara klasikal dan bukan merupakan suatu proses untuk menjalankan sebuah instruksi baku yang telah dirancang (Tim BelmawaDikti, 2014: 54). Dalam praktiknya, prinsip student center learning dapat ditunjukkan dengan penggunaan metode pembelajaran seperti cooperative learning, problem based learning, discovery learning oleh dosen. Metode pembelajaran dapat dikembangkan sendiri oleh dosen yang mengacu pada prinsip student center learning.

Berdasarkan hasil observasi pembelajaran dan wawancara tanggal 13 Oktober 2016 terhadap dosen ditemukan bahwa metode pembelajaran yang paling sering digunakan adalah presentasi dan diskusi kelas. Selain presentasi dan diskusi kelas juga digunakan metode peer teaching dan small group discussion. Metode peer teaching digunakan dalam mata kuliah psikologi pendidikan dan small group discussion digunakan dalam pembelajaran mata kuliah ilmu pendidikan Islam. Saat dilakukan observasi terhadap pembelajaran psikologi pendidikan, dosen menggunakan metode presentasi dan diskusi kelas. Suasan kelas kondusif dan mahasiswa terlihat antusias dalam mengikuti pembelajaran. Hal tersebut sesuai dengan hasil wawancara dengan Salis Wahyu Hidayati sebagai pengampu mata kuliah psikologi pendidikan bahwa fokus utama yang diharapkan adalah agar mahasiswa lebih aktif dalam mengikuti pembelajaran yang dilakukan (Wawancara bersama Salis Wahyu Hidayati tanggal 5 Oktober 2016). Bahkan hasil focus group discussion yang terdiri dari mahasiswa semester 1 dan 3 berpendapat bahwa salah satu pembelajaran yang mengasyikkan adalah mata kuliah psikologi pendidikan. Alasan mereka adalah ada tugas mengupas film pendidikan "laskar pelangi" sebagai tugas mata kuliah (FGD mahasiswa semester 1 dan 3 pada tanggal 19 Oktober 2016). Berdasarkan data tersebut, mata kuliah psikologi pendidikan sebenarnya telah menerapkan prinsip-prinsip student center learning atau sesuai dengan yang diharapkan oleh paradigma pembelajaran berdasarkan kurikulum KKNI. Meskipun perencanaan yang dibuat belum menunjukkan kesesuaiannya dengan capaian pembelajaran dalam kurikulum berbasis KKNI.

Dari hasil observasi partisipatif oleh peneliti sendiri, penggunaan metode small group discussion terlihat lebih efektif dibanding dengan diskusi kelas. Hal tersebut dilihat dari respon mahasiswa dan keaktifan mahasiswa dalam setiap kelompok kecil yang telah dibuat. Mahasiswa dibagi menjadi tiga kelompok kecil untuk mendiskusikan tema perkuliahan ilmu pendidikan Islam. Tiap kelompok terdapat mahasiswa yang mempresentasikan makalahnya (Observasi partisipatif tanggal 17 Oktober 2016). Dari hasil FGD sendiri, pembelajaran ilmu pendidikan Islam belum sesuai dengan harapan mahasiswa. Menurut mereka, pembelajaran ilmu pendidikan Islam terlalu kaku (FGD mahasiswa semester 1 dan 3 pada tanggal 19 Oktober 2016). 
Sedangkan dalam pembelajaran metodologi studi Islam, metode yang digunakan adalah presentasi dan diskusi kelas. Dari hasil observasi terhadap pembelajarannya, mahasiswa mempresentasikan makalah secara kelompok. Kemudian terdapat sesi tanya jawab dan diakhir pembelajaran dosen memberi tambahan materi yang belum dikupas dalam diskusi kelas sebelumnya (Observasi Pembelajaran Metodologi Studi Islam pada tanggal 4 Oktober 2016). Sedangkan hasil wawancara dengan dosen pengampu didapatkan bahwa pembelajaran yang dilakukan difokuskan pada keaktifan mahasiswa sehingga metode yang digunakan adalah presentasi dan diskusi kelas (Wawancara dengan Muhtar Sofwan Hidayat tanggal 12 Oktober 2016).

Dari informasi di atas, pelaksanaan pembelajaran sebenarnya telah mengacu prinsip student center learning. Dalam konteks penerapan kurikulum berbasis KKNI prodi PGMI, hanya ketidaksesuaian capaian pembelajaran saja yang menjadi problem utama.

Selain dianalisa dari penggunaan metode pembelajaran di kelas, pelaksanaan pembelajaran dapat dilihat dari prespektif peran dosen dan mahasiswa. Belmawa-Dikti menyebutkan bahwa peran dosen dalam pelaksanaan pembelajaran student center learning yaitu dosen bertindak sebagai fasilitator, dosen mengkaji capaian pembelajaran mata kuliah, merancang strategi dan lingkungan belajar yang memperkaya pengalaman belajar mahasiswa, dosen membantu mahasiswa dalam mengakses, menata dan mengkonstruksi informasi untuk dimanfaatkan dalam pemecahan masalah aktual, dan dosen menentukan pola penilaian yang sesuai dengan capaian pembelajaran yang akan diukur (Tim Belmawa-Dikti, 2014: 58-59).

Dari hasil reduksi data penelitian dilapangan mengenai pelaksanaan pembelajaran dilihat dari segi peran dosen dan mahasiswa dapat diperoleh analisa sebagai berikut:

a. Dosen mampu berperan sebagai fasilitator dalam upaya membantu mahasiswa melaksanakan pembelajarannya.

b. Dosen belum mengkaji capaian pembelajaran sesuai dengan rumusan dalam kurikulum berbasis KKNI prodi PGMI.

c. Dosen kurang mampu merekayasa lingkungan belajar sebagai upaya membangkitkan motivasi belajar mahasiswa secara mandiri.

d. Mahasiswa lebih menyukai pembelajaran yang humoris.

e. Dalam merencanakan pembelajaran secara individu seperti membaca referensi mata kuliah sebelum kuliah berlangsung belum secara merata dilakukan oleh mahasiswa.

Pelaksanaan pembelajaran dengan mengacu pada kurikulum berbasis KKNI prodi PGMI belum dapat terlihat sepenuhnya. Hal tersebut disebabkan oleh dokumen kurikulum yang belum final dan pemahaman dosen mengenai kurikulum berbasis KKNI yang bersifat pas-pasan.

Penilaian. Dalam permendikbud Nomor 49 Tahun 2014, penilaian diartikan sebagai kriteria minimal tentang penilaian proses dan hasil belajar mahasiswa dalam rangka pemenuhan capaian pembelajaran lulusan. Penilaian proses dan hasil belajar mahasiswa mencakup prinsip penilaian, teknik dan instrument penilaian, mekanisme dan prosedur penilaian, pelaporan penilaian dan kelulusan mahasiswa. 
Untuk penilaian proses pembelajaran dalam paradigma pembelajaran student center learning dilakukan selama proses dengan melihat perkembangan hasil di beberapa tahapan pembelajaran. Model penilaian yang digunakan adalah penilaian kinerja (authentic assessment atau performance assessment). Dalam penilaian kinerja terdapat tiga aktivitas dasar yaitu dosen memberi tugas, mahasiswa menunjukkan kinerjanya dan dinilai berdasarkan indikator tertentu dengan instrument yang disebut rubric (Tim Belmawa-Dikti, 2014: 70). Jika dosen melaksanakan penilaian terhadap kinerja mahasiswa sesuai dengan indikator pembelajaran yang mengacu pada capaian pembelajaran mata kuliah, maka dosen tersebut telah melaksanakan pembelajaran yang mengacu pada kurikulum berbasis KKNI.

Dalam pelaksanaan penilaian ini, pembelajaran pada prodi PGMI dapat dianalisa dengan teknik triangulasi sumber maupun triangulasi teknik. Hasilnya adalah dari tiga aktivitas dasar penilaian hanya dua yang dijalankan secara maksimal yaitu dosen memberi tugas dan mahasiswa menunjukkan kinerjanya. Sedangkan untuk aktivitas dinilai berdasarkan indikator dan instrument tertentu belum secara maksimal dilaksanakan. Hal tersebut dilihat dari tidak adanya instrument penilaian yang dimiliki oleh dosen.

Penilaian yang dilakukan oleh dosen hanya mengandalkan observasi terhadap presentasi makalah dan keaktifan, penilaian UTS dan UAS. Sedangkan bukti otentik mengenai instrument penilaian yang digunakan tidak ditemukan. Peneliti hanya menemukan satu instrument penilaian makalah dan presentasi untuk mata kuliah ilmu pendidikan Islam. Instrument tersebut disusun untuk menilai presentasi mahasiswa dalam setiap kali pertemuan. Uraian dalam instrument tersebut terdiri dari kriteria penilaian makalah dan kriteria penilaian presentasi (penyajian dan tanya jawab).

Dari data tersebut, penerapan kurikulum berbasis KKNI prodi PGMI pada aspek penilaian juga belum dapat berjalan secara maksimal seperti pada aspek pelaksanaan pembelajarannya.

\section{Faktor Pendukung dan Penghambat}

a. Tahap Penyusunan Kurikulum

Dalam tahap penyusunan kurikulum ini, kendala utama dalam proses penyusunan kurikulum berbasis KKNI prodi PGMI adalah minimnya pendampingan oleh ahli kurikulum sehingga dokumen yang dihasilkan tidak sempurna (Wawancara dengan Arina Hidayati dan Muhtar Sofwan Hidayat (Tim Pengembang Kurikulum PGMI) tanggal 22 September 2016). Selain itu, waktu enam bulan yang tersedia dalam penyusunan kurikulum berbasis KKNI ini dirasa sangat kurang. Hal tersebut berdampak pada proses penerapan selanjutnya.

\section{b. Tahap Persiapan Penerapan Kurikulum}

Kendala utama dalam tahap persiapan penerapan kurikulum ini adalah dokumen kurikulum berbasis KKNI prodi PGMI yang belum bersifat sempurna. Dalam sosialisasi 
kepada dosen PGMI juga berjalan tidak maksimal. Hal tersebut berakibat pada ketidaksiapan dosen dalam melaksanakan pembelajaran yang mengacu pada kurikulum berbasis KKNI. Ketidaksiapan dosen tersebut terlihat dari dokumen perencanaan yang telah dibuat di mana tidak sesuai dengan capaian pembelajaran yang telah dirumuskan sebelumnya. Padahal, dilihat dari segi kualifikasi dosen sudah cukup baik yaitu dosen PGMI semua telah berpendidikan minimal strata 2.

Selanjutnya, dilihat dari segi faktor pendukungnya, persiapan penerapan kurikulum ini telah difasilitasi baik oleh universitas maupun fakultas. Universitas mendatangkan keynote speaker ahli kurikulum KKNI dan Fakultas membetuk tim khusus pengembang kurikulum program studi. Sarana prasarana yang dimiliki prodi PGMI juga menjadi faktor pendukung lain yaitu dengan adanya laboratorium MIPA, perpustakaan, ruang mikro teaching dan juga SD al-Madina sebagai sekolah laboratorium yang dimiliki oleh FITK. Hanya saja semua sarana prasarana tersebut belum dimanfaatkan secara maksimal dalam konteks penerapan kurikulum berbasis KKNI.

\section{c. Tahap Pelaksanaan Kurikulum}

Sebagai dampak lanjutan dari kendala-kendala sebelumnya, pelaksanaan pembelajaran dengan mengacu pada kurikulum berbasis KKNI prodi PGMI ini adalah berjalan apa adanya. Dosen tidak memiliki pemahaman sempurna terkait kurikulum berbasis KKNI sehingga penerapan kurikulum ini masih bersifat ujicoba. Selain itu, tim pengembang kurikulum juga belum mampu menjelaskan secara baik bagaimana konsep penerapan kurikulum berbasis KKNI yang telah disusun tersebut sehingga sosialisasi kepada dosen tidak berjalan efektif.

Meskipun demikian, secara substansial, beberapa dosen telah melaksanakan kurikulum berbasis KKNI dengan upayanya yang mengadakan pembelajaran bersifat student center learning. Artinya, dosen-dosen PGMI tersebut termasuk menjadi faktor pendukung dalam pelaksanaan kurikulum berbasis KKNI pada prodi PGMI.

\section{Dampak Penerapan Kurikulum Berbasis KKNI}

Dampak dari penerapan kurikulum berbasis KKNI prodi PGMI yang sangat terlihat adalah penataan mata kuliah-mata kuliah pada prodi PGMI UNSIQ. Sebelumnya, beberapa mata kuliah dalam struktur kurikulum prodi PGMI tidak menunjukkan korelasi antara kemampuan yang harus dikuasai mahasiswa dengan pencapaian profil lulusan. Peneliti menemukan satu mata kuliah yang dihilangkan akibat dari diterapkannya kurikulum berbasis KKNI ini yaitu mata kuliah scolastik pendidikan. Dengan disusun ulang struktur kurikulum prodi PGMI yang mengacu pada kurikulum berbasis KKNI ini, bahan kajian atau mata kuliah yang dirancang setidaknya tidak berbeda secara signifikan dengan bahan kajian yang dimiliki oleh prodi PGMI di luar UNSIQ.

Sedangkan untuk dampak penerapan kurikulum berbasis KKNI prodi PGMI terhadap mahasiswa belum dapat terlihat. Hal tersebut dikarenakan, dari hasil analisa 
yang ditemukan bahwa penerapan kurikulum berbasis KKNI prodi PGMI memang baru memasuki tahap ujicoba.

\section{Kesimpulan}

Secara kronologis, proses penyusunan kurikulum dari mulai Januari 2015 sampai Juli 2015 hanya menghasilkan pemahaman yang parsial tentang kurikulum berbasis KKNI prodi PGMI bagi tim pengembang kurikulum. Penerapan kurikulum berbasis KKNI pada tahun ajaran 2015/2016 memasuki tahap pengenalan secara mendalam baik untuk tim pengembang kurikulum maupun dosen PGMI. Sedangkan tahun ajaran 2016/2017 ini masuk dalam tahap ujicoba kurikulum.

\section{Daftar Pustaka}

Casmini. Evaluasi dan Peninjauan Kurikulum BKI berbasis KKNI, Jurnal Hisbah, Vol. 11, No. 1, Juni 2014.

Dikti. 2010. Buku Pedoman KKNI. Jakarta: Kemendiknas.

Hasanah, Nur. 2014. Kesiapan Perguruan Tinggi Dalam Menerapkan Kurikulum Berbasis KKNI (Studi Kasus di Fakultas Tarbiyah dan Keguruan IAIN Ambon), Jurnal Fikratuna, Volume 6 No. 2, Juli-Desember 2014.

Milles, Mattew B and A Mitchel Huberman. 1993. Analisa Data Kualitatif, Ter.. Tjetjep Rohandi R. Jakarta: UI-Press.

Permendikbud No. 49 Tahun 2014 Tentang Standar Nasional Pendidikan Tinggi

Permendikbud No. 73 Tahun 2013 tentang Penerapan KKNI

Ridwan, Achmad. 2016. Modul 2 Implementasi Kurikulum dalam http://baa.unas.ac.id. tanggal akses 5 Maret 2016.

Rohman, Arif. 2009. Politik Ideologi Pendidikan. Yogyakarta: LaksBang Mediatama.

Solikhah, Imroatus. 2015. KKNI dalam Kurikulum Berbasis Learning Outcomes, Jurnal LINGUA, Vol. 12, No. 1, Maret 2015.

Sulistyastuti, Dyah Ratih. 2012. Implementasi Kebijakan Publik: Konsep dan Aplikasinya di Indonesia. Yogyakarta: Gava Media.

Tim BELMAWA-DIKTI. 2014. Panduan Penyusunan Capaian Pembelajaran Lulusan Program Studi, Jakarta: Direktorat Pembelajaran \& Kemahasiswaan Ditjen-Dikti. Wahab, Sholichin Abdul. 2008. Analisis Kebijaksanaan, Dari Formulasi ke Implementasi Kebijaksanaan Negara. Jakarta: Bumi Aksara.

www.edukasi.fajarnews.com, tanggal akses 23 April 2016 